\title{
RECONSTRUCTION AND THE LEGAL PROFESSION ${ }^{1}$
}

\author{
Thomas W. Swan
}

Yale University School of Law

The Great War has brought every country of Europe face to face with vast and critical problems of Reconstruction-political, economic, social. Our own country also, in its political, economic and social institutions, feels the tremors of the great European convulsion. Despite the immunity of our land from devastation and our comparative freedom from the burdens of the conflict, our participation in the war has brought us problems of critical importance to the continuance of our political and social structure. What are to be our international relations of the future? What is to be our domestic polity with respect to the division of powers between the national government and the states? Under the pressure of war emergencies the national government has vastly extended its control over the activities of the individual. It has regulated the prices at which we could buy our bread and our coal; it has built houses for certain of its employees; it has taken over the control and management of various public utilities. People are asking whether such governmental activities should be abandoned in time of peace; whether vital necessities such as transportation systems, telegraphs, coal miries, should be returned to private ownership and operation just as before the war. The cost of creating vast armies, of enlarging our navy, and of developing a merchant marine has raised new problems of government finance. Lastly, and more important than all in my judgment, are the problems relating to the relations of capital and labor, and to the preservation of our institutions against the menace of unrest and extreme radicalism called Bolshevism.

These are some of the problems which face the legal profession as a result of the war. They face not only the lawyers, they face every citizen, every member of every community in the country. They are questions of public policy depending for their answer upon the will of the majority of the people. Only by the creation of an enlightened and intelligent public opinion by free discussion can they be solved correctly.

In such a time as this the highest conception of the professional duty of the lawyer requires him to contribute to the thought of the country upon questions of public policy. It is the duty of every citizen

\footnotetext{
${ }^{1}$ An address delivered May Io, I9I9, as one of a series of "Reconstruction Lectures" arranged by Yale University on the Dodge Foundation for Yale Lectures on the Responsibilities of Citizenship.
} 
of course to give his best thought to political problems, but this is preeminently true of the lawyer, both because his training and experience should fit him better than many citizens to form an intelligent opinion on political questions, and because lawyers play a large part in legislation.

The influence of the legal profession upon public affairs has been noted by many commentators upon American life and institutions. James Bryce in The American Commonwealth called attention to the fact that from the days of Patrick Henry and John Jay and John Adams down to the time of Abraham Lincoln many-perhaps mostof the leading statesmen of the country were drawn from the legal profession. This profession held a preëminent place of political and social prestige. In later years, indeed, there has come a diminution in its political authority and a decline in its social standing. With the development of party organization, it became more difficult for the leaders of the bar to obtain public office without devoting themselves to professional politics to the exclusion of the practice of law. With the increase of accumulated wealth in the hands of individuals and of corporations, the financial inducements of practice were increased, and law has become more of a business. The lawyers have lost, while the capitalists have gained, in political influence. With the more general diffusion of education, the relative superiority of the lawyer class in education has diminished, with a consequent loss of prestige socially. Other professions also have similarly lost in this regard.

But it is still true that lawyers as a class play a large part in public affairs. In the legislative halls, in the executive chambers, in the administrative bureaus of the national, state and city governments, a relatively high percentage of important positions is still filled by lawyers. It is still true that leaders of the bar may exert a wide influence in the formation of public opinion. To the legal profession, then, the call to think upon these great problems of reconstruction comes more clearly, more imperatively, than to any other group in the community. As was said by Mr. Henry W. Taft in addressing recently the New York State Bar Association :2

"To the extent that lawyers aid unselfishly and effectively in the solution of such great problems as these, to that extent, and to that extent only, will they place themselves in the position of influence which the bar occupied in the first half of the history of the nation. But they must move out of the atmosphere of private interests and not let their opinions on public questions be fettered by the pecuniary interests of their clients, or confine their thoughts as citizens upon great constitutional questions of the day within the narrow channel of personal interest. Above all things they must have courage and

\footnotetext{
${ }^{2}$ Forty-second Annual Meeting-Remarks of Henry W. Taft at the Annual Dinner, New York, January I8, rgrg.
} 
initiative. They must not only contribute to the discussion but they must lead in a constructive way. If they do this, they may again find themselves the most influential element for good in our body politic."

Problems of Reconstruction not only offer to the leaders of the bar the opportunity, but they also impose the duty, to exercise the highest function of the lawyer-namely, to think as a statesman and to help to mold public opinion wisely on the important political questions with which the war has brought us face to face.

A second duty which the so-called period of Reconstruction imposes upon the legal profession is the duty to take account of stock, to examine critically the laws under which we are living and the administration of those laws. The spirit of unrest and discontent which follows every great war subjects all of a nation's institutions to a more searching scrutiny than they have to endure in normal times. What will the lawyer find if he critically inspects the habiliments and ministrations of his goddess-Law?

The object of law is the attainment of justice between man and man. Certain rules of conduct are thought to work justice and are enforced as laws. But to do justice laws should operate uniformly under like circumstances; they should operate with certainty, so that a man may know what is lawful and what unlawful; they should operate promptly. Acquittal will seem scant justice to the innocent prisoner who has languished three months in jail awaiting trial, and the man whose property has been unlawfully taken by another will feel aggrieved even though he ultimately collects a judgment, if the courts have been so clogged that he has had to take three years to obtain satisfaction from the wrongdoer.

If the lawyer takes an account of stock in respect to these three points, uniformity, certainty, and promptness of administration, he will be forced to recognize that at least some of the criticism, which for many years has been levelled against the law, is fair. Admitting that a certain amount of delay is inevitable, and making allowance for unavoidable uncertainty and lack of uniformity because law must be administered by finite human agents, there will still remain a residuum of justifiable criticism.

No critic, however, is qualified to approach the question unless he comprehends something of the way in which our law originated and has developed. The basis of American law is the common law of England. Its roots go back to the customs and mores of the AngloSaxons even prior to the Norman conquest and the days of feudalism. With changing times and changing conditions it has grown as the shore grows by adding grains of sand countless in number. Each judgment of a court decides the precise controversy between the litigants, and only by examining the reports of many such decisions can one deduce the general rule of conduct which is the law for a particular 
situation. Of course the common law has been supplemented and modified by statute, but even when one is considering a statutory rule of conduct he must look to the courts' decisions to find how the statute has been interpreted, in order to be able to prophecy what the law will be held to be in any given state of facts.

When we realize that in the United States each state has its own common law and its own statute law and that the decisions of the courts of one state are merely persuasive, not controlling, in determining the law of another, it is easy to see what an opportunity for uncertainty exists. Of course the similarity in the law of different states is great, the divergence relatively slight, but still the theory of our legal institutions is that each of our forty-eight states has its own system of law. An act which may be lawful in Connecticut may be unlawful if done across the line in Massachusetts, and a contract valid in New York may be unenforceable in Illinois.

The difficulty of the lawyer in such a system is so obvious as to require little elaboration. His clients, especially if the client be a corporation, may be doing business in every one of the states. $\mathrm{He}$ must be able to advise the client not on the law of one state but on the law of forty-eight. Knowledge of the law, says Mr. Justice Holmes, in substance, is the ability to predict what the courts will do. To obtain such ability the lawyer must know what the courts have done in like circumstances. When we consider that in one year the Court of Appeals of the state of New York handed down decisions which cover more than two thousand printed pages of the official reports, that the lower New York courts are deciding cases whose reports are even more voluminous, and that a similar process is going on in every state in the Union, the pitiable plight of the man whose ambition is to know the law is apparent! John Bassett Moore has described the place occupied by judicial decisions in our legal system in words which warrant quotation : ${ }^{3}$

"We have spoken of the annual 'output' of judicial reports, and the phrase, with its thrifty flavor, is deliberately chosen; for the publication of reports is little regulated and thoroughly commercialized. With each court there is connected a pipe promptly to convey its products to the great center of distribution; and from this center, day by day, month by month, year by year, there is poured out, as through a great main, upon a gurgling, gasping, sputtering Bar, a turgid stream of judicial decisions. Here there is no discrimination, no estimation of merit or of importance. Cases petty and cases important, cases of national interest and cases of interest purely local, final decisions, and decisions either reversed or on the way to reversal, are, with generous impartiality, spread broadcast over the entire land.

"This system is supported by the Bar with mingled feelings of grati-

sAddress before the Alumni of the Law School of the University of Pennsylvania. See (rgi4) 62 U. of PA. L. Rev. 525, 538. 
tude and despair; for the Bar is conscious of the fact that while it is in a sense served by the system, it is also enslaved and debauched by it. The very multiplicity of cases, and the consequent impossibility of dealing with them scientifically, reduces practitioners to a reliance upon particular decisions rather than upon general principles; and this in turn accentuates the tendency, long ago abnormally developed, to pay undue respect to mere cases as authority. How often do counsel produce with an air of triumph the latest decision, rendered perhaps in some far-off jurisdiction by a judge whose opinions derive their weight solely from his official position. How often, too, do they cite cases in their briefs indiscriminately. Some years ago the statement was made that in a single volume of reports then lately published more than 5,000 cases were cited, and although this number would seem to suffice, possibly it may since have been exceeded."

This mass of authorities rolls down upon the lawyer in great black clouds. No wonder there is some uncertainty in the law!

What is the way out of the morass? How shall we attain greater certainty and uniformity in the law? Scientific reporting of decisions would help. A single supreme court having jurisdiction to review judgments of the highest state tribunals would exert a unifying influence.* But the most hopeful path leads in the direction of scientific codification, coupled with a plan for periodic revision.

This suggestion for a scientific codification of the law is not a new idea. It has long been agitated. But it is appropriate to mention it here because in taking stock of our legal institutions, as we ought to do in this reconstruction period of critical scrutiny, it is one of the ways of improving our law which offers most hope of success.

Something along the line of codification has already been attempted. The American Bar Association long ago initiated a Commission on Uniform State Laws, to which numerous states have appointed commissioners, and some progress has been made in adopting uniform codes on special topics, such as the Uniform Negotiable Instruments Law, the Uniform Sales Act, the Uniform Bills of Lading Act, and others. But we are still far from our goal.

The process of scientific codification of the law is no easy task. The codifier must know the origin and history of a rule before he can wisely determine whether to embody it in the code, or to modify or to reject it. He must have the power to analyze legal relations before he can engage in synthesis and codification. He should have definite concepts of what he means by terms which define legal relations, and an accurate terminology to describe such concepts. In certain spheres of economic or social activity he should have before him the experience of Europe, and should draw from the laws and practice of other nations such rules as may wisely be incorporated into his own code.

'See Herbert Pope, The Federal Courts and $A$ Uniform Law (rgrg) 28 YALE LAW JOURNAL, 647 . 
Thus it appears that the men who are to be our codifiers must be adequately trained. The difficulty of finding such trained codifiers was emphasized by Mr. Elihu Root in addressing the American Bar Association: ${ }^{5}$

"Some very able and public spirited lawyers have been for some years urging the organization of a definite and specific movement for the restatement of our law; for a new American Corpus Juris Civilis. They are quite right. It ought to be done. But who is to do it, and how shall he be recognized as a prophet?"

Codification cannot be carried out in haste. Germany before adopting her Code of 1896 spent 22 years in its preparation. Preliminary drafts were submitted not only to lawyers and law professors but also to business men, financiers, men of affairs in numerous walks of life, in order that their suggestions and reactions could be availed of before the proposed rules were finally enacted. Such a method must be employed here in our codification. A code will not be worth the paper on which it is written unless it is in tune with the practices and ideals of the people whose conduct it is to govern. It must not be a winding sheet of dead and outgrown laws.

For the same reason, periodic revisions of any codification will pro- bably be necessary. The law is a vital, living, changing thing which must keep pace with the changing ideals and mores of the community. The danger of a code is that it will become a mere catalogue of arbitrary rules, less flexible in application than our present system of case law. For that reason it must not be too detailed, but should allow the courts some discretion in molding the general rule to fit special facts.

I have referred to the desirability of drawing upon the experience of other countries in codifying our law. Indeed, without waiting for any complete codification immediate reform of our law ought to be made in certain respects by borrowing from the experience of other lands. To cite a single example, we might immensely improve our legal machinery by adopting the procedure known in England and a number of European countries, as the declaratory judgment. Let me give a concrete illustration of the need for this reform. Suppose two men enter into a contract-for instance, that one shall later deliver to the other goods of a certain description-and a dispute arises between them as to what the contract requires; our law provides no method of obtaining a legal determination of that dispute until one party has broken the contract and the other has sued for damages. What a cumbersome method of procedure to require your contract to be broken before the court will tell you what it means! Where the declaratory judgment is permitted, a party to the contract under the supposed cir-

* (Igr6) 4 I Rep. Am. Bar Assn. 365. 
cumstances could apply to a court and obtain a declaration of his rights or duties; and a party having thus found out his legal duty is likely to perform it. In this country, on the contrary, he can only find it out by taking his own view of the contract and letting the court tell him later whether he guessed right or guessed wrong; and if he guessed wrong of course he has to pay damages to the other party. The principle of the declaratory judgment has an application much wider than to contracts only. The courts should be able to declare the legal relations of the parties in any situation where a dispute has arisen. In certain classes of cases, such as injunctions or bills to construe a will, our law already recognizes a procedure which is in substance the same as the declaratory judgment; but the cases where such proceedings are permissible are at present far too limited. The adoption of the declaratory judgment is a striking example of a legal reform which we should borrow at once from the experience of other countries.

In recent years there has developed a marked tendency to take litigation away from our courts and to place it in the hands of administrative officials or commissions. Consider such bodies as the Interstate Commerce Commission, the numerous state Public Utilities Commissions and the officials who enforce workmen's compensation laws. Such commissions are invading what was formerly the province of the courts. They are deciding not only controversies in which the public has a direct interest, as in the matter of railroad and other utilities rates, but also controversies between man and man, as in the case of workmen's compensation, and they are doing it more promptly, with less cumbersome machinery, and apparently with greater satisfaction to the public than do the courts. These bodies administer the law without formal pleadings, without technical rules of evidence, without juries and one might almost say without lawyers, for while the parties may be represented by attorneys, the conduct of the case is controlled much more by the commission than by the trial attorneyswhich is just the reverse of the procedure in court trials. A concrete illustration will show more graphically the procedure. Let me give you Professor Willis' description of a case before the California Industrial Accident Commission :?

"When an injured employee has been refused indemnity for disability and he feels that he is entitled to it, he simply states the facts to the commission in writing. Should he omit material facts, they may be supplied later by himself or by reference to the testimony. The parties against whom the claim is made cannot demur, but they may or may not file an answer. If they do, no particular form is required.

\footnotetext{
- See Edwin M. Borchard, The Declaratory Judgment-A Needed Procedural Reform (1918) 28 Yale LAW JourNaI, I, 105.

${ }^{i}$ See Hugh Evander Willis, Our Impending Law Reform (IgIg) 9 U. of N. DAK. QUART. JOUR, 155, 158.
} 
If they do not, there is no default. Upon application of the claimant, notice is given to the defendant by mail, with a copy of the application; and service of any other process thruout the proceeding is made in the same way. Such service is found wholly satisfactory. The essential thing is notice to the adverse party of what is going on, and it is found that there is no better, or quicker, or more economical way to give notice than thru the mails. Cases are set for hearing in not less than ten nor more than forty days after the application is filed. The hearing is before the commission, or a commissioner, or a referee. Whoever hears the case advises the parties of the provisions of the law, and requests them to agree upon such matters as are not in controversy. There are generally only one or two matters upon which they do not agree. Then the referee, or commissioner, examines the witnesses. Rules of evidence are not observed. Leading questions and any other question that a business man would put in investigating a transaction are asked. Additional questions may be asked by the parties or their representatives, but when the commissioner, or referee, has finished his examination there is usually nothing left uncovered. If expert medical testimony is involved, it is the practice for the commission to appoint a professional expert. Stenographic notes are taken. The great bulk of the cases are finally decided in less time than it ordinarily takes to get past the demurrer stage in a court of law in California. (Ninety days as compared with five years.)"

This method of administering justice by commissions is symptomatic of a widespread discontent with the delay and technicality of procedure in courts of law. It is a method which may be expected to develop and to extend more and more into the field of the law courts. It behooves the legal profession to take note of it, and to adopt so much as is good, in reforming the procedure of the courts. England has already gone much farther than we in her reform of legal procedure. In Europe administrative tribunals such as $I$ have been considering play a large part in the legal system.

One other feature of law reform I wish to mention briefly-the need of reforming legislative methods. "There is a useless lawsuit in every useless word of a statute; and every loose, sloppy phrase plays the part of the typhoid carrier," said Mr. Root in the address from which I have already quoted. What he was referring to was the economic waste of a lawsuit brought about because faulty draftsmanship of a statute rendered its meaning uncertain. Every one who has attempted to express his meaning in writing with accuracy will realize the skill required in a competent statutory draftsman, and yet under our legislative system every member of Congress or of a state legislature is at liberty to draw and introduce a bill on any subject, and scarcely one of them doubts his ability to do so. Parliamentary draftsmen should be provided by every legislature. A few states have already done this, and Congress has recently appointed technical aides of this character for the House and Senate. Improvement in legislation by such means will save much litigation. 
I have suggested four subjects of needed law reform of which the legal profession should take cognizance at this period when all of our institutions are being subjected to critical scrutiny. No doubt additional subjects might be suggested, but these four are sufficient for consideration this evening. They are (I) scientific codification, (2). drawing upon the experience of foreign countries for specific improvements, such, for one example, as the declaratory judgment, (3) the reform of court procedure and of technical rules of evidence by the utilization of practices already common in the administration of justice by commissions, and (4) the appointment of skilled draftsmen to aid in legislation.

Closely connected with the subject of law reform, indeed absolutely essential to its successful progress, is another needed reform and one which is particularly near to my heart. I refer to improvement in legal education.

The lawyers of the country must be the leaders in law reform; and where shall we find lawyers possessing adequate knowledge of legal history, of foreign legal institutions, of sociology, of economics, of political science, of analytical jurisprudence, to enable them to carry out this great task of scientific codification and reform of the law? Our law schools with few exceptions have devoted themselves almost exclusively to the training of young men to make their living by practice at the bar. They have indeed tried to attain this object by scientific methods of instruction, but few of them have recognized the opportunities and responsibilities with regard to the broader and greater service which present day conditions are demanding. This limitation of our legal education was recognized by Justice Francis M. Finch when, after a long experience as a member of the New York Court of Appeals, he said:

"In this country it is a national fault that we make lawyers, but never jurists; we study law as an art, but never as a science. That fault is an outcome of our intensely practical lives-never inclined to ask why, but always determined to know what. The mistake of it lies in this: Law is not a mere catalogue of arbitrary rules. If that were so, to know those rules would be enough. Law is a growth, and is growing yet, and will continue to grow when you and I are gone. ...."

"I would not say. . . that our whole system of study should be overthrown and in its place be put the study of law as a science and not merely as an art; but I do say that it is a shame to graduate a lawyer densely and absolutely ignorant of the history of his own profession; and that it is entirely possible with a better preparation and a longer course to parallel the lines of technical study with the elements of jurisprudence and the story of the law's share in the progress of civilization. If there were no other single reason for increasing the required preparation and lengthening terms of study, I should deem it an all-sufficient one that the change will furnish opportunity for and open the way to a study of the science of juris- 
prudence, and will tend to make our young men, not merely technical practitioners, but strong, intelligent, scholarly lawyers, and, what is equally needed, strong, intelligent and scholarly men . . . They are to be our leaders, our civic rulers, our law makers."

President Frank J. Goodnow of Johns Hopkins University in addressing the American Bar Association in $1916^{8}$ emphasized the need that

"somewhere in the United States, preferably in connection with some one of our universities, there should be established a school or department not for the education of lawyers for the practice of the law, but for the study of jurisprudence, in which greater attention might be given than is now possible to the solution of the many legal and political problems which the great changes in our economic and social life are with increasing emphasis bringing to our attention."

\section{A similar thought has been expressed by Mr. Elihu Root:}

"The only way to clarify and simplify our law as a whole is to reach the lawyer in the making and mold his habits of thought by adequate instruction and training so that when he comes to the Bar he will have learned to think not merely in terms of law but in terms of jurisprudence. . . . With a Bar subjected generally to that process of instruction, the more general systematic study of jurisprudence would follow naturally and inevitably, and the influence of that study would be universal; and from that condition would evolve naturally the systematic restatement of our law, by men equal to that great work."

Not only must we have lawyers and judges capable of leading in the legal development of the future, we must have a third group of workers- jurists broadly trained for service in many fields of useful and far reaching activity. Our universities should be training expert advisers in legislation of all kinds, skilled draftsmen, competent men for revision and codification, and men able to restate and simplify the common or unwritten law in all its various fields. This need can be met nowhere else than in a school of jurisprudence.

It is not enough to train men merely in the art of practicing law. This is important, and the proposal to improve legal education does not contemplate any lessening in the practical equipment of the practicing lawyer. But to this practical instruction should be added a broader foundation for all, and for some few the opportunity to continue their studies with a view to becoming scientific jurists. Yale is one of the few schools that for nearly half a century has recognized this ideal. The work was begun as early as 1875 under the inspiration and leadership of Governor Baldwin, who for many years, and long before the necessity for the new development had been so generally recognized, had the wisdom and vision to appreciate the benefits to be gained by

(1916) 4I Rep. Am. Bar Assn. 423.

'(rgr6) 4r Rep. Am. Bar Assn. 366. 
broadening the law school curriculum. Further progress in this direction was greatly stimulated by the constructive imagination of the late Professor Hohfeld. ${ }^{10}$ In all the leading law schools the student is now trained in the original determination of legal principles by the case method, a comparative and critical study of the decisions of courts along historical lines. To this must be added more efficient methods of analysis, a more exact terminology and a more vivid conception of the mores as the source of law. In all the universities closer connection should be established between the schools of law and the departments of social science, political science, economics, history, and psychology. In these departments we need groups of ambitious, enthusiastic, and progressive men who understand and are ready to coöperate in legal development.

I cannot close my remarks on legal education more fittingly than to 'quote the eloquent words of President Woolsey in an address delivered in I874 on the fiftieth anniversary of the founding of the Law Department at Yale:

"At this point, when I am about to close my address, I cannot help offering to my hearers a view of a law school which although only ideal and possible at present, deserves to be looked at with attention. . . . . Let the school, then, be regarded no longer as simply the place for training men to plead causes, to give advice to clients, to defend criminals; but let it be regarded as the place of instruction in all sound learning relating to the foundations of justice, the history of law, the doctrine of government, to all those branches of knowledge which the most finished statesman and legislator ought to know. . . . I present the idea in the hope that some man who can estimate the value of great and useful plans, and has the means to effect them, may be disposed by what I have said, or others hereafter may say better, to turn the idea into a reality."

The idea is being turned into a reality, but it must be more fully realized that a scientific school of jurisprudence, unlike a mere "trade" school, requires the support both moral and financial of the legal profession. Very gradually President Woolsey's splendid ideal of legal education is making its way. In the years just before us I foresee more rapid and more general progress in the improvement of legal education.

This period of Reconstruction should bring home to the legal profession not only its duty to lead public opinion on critical political and social problems which confront our nation, not only its duty to reform defects in the law and its administration, but also its duty to aid in so broadening and deepening legal education that the lawyers of the future may render a larger public service.

\footnotetext{
${ }^{10}$ See Wesley Newcomb Hohfeld, $A$ Vital School of Jurisprudence and Law (IgI4) Proc. I4th Annual Meeting of Assn. of Am. Law Schools, 76.
} 